\title{
And the Open Bridge: Labour, Enchantment, There Forever
}

\author{
Linda Marie Walker and Stephen Loo
}

\begin{abstract}
The bland does not utter the things of the world -does not paint the world - except at their point of assimilation back into the Undifferentiated, where they shed their distinctive traits, integrate their differences, and give reign to their propensity for fusion. An imponderable quality ... blandness is, of necessity, fugitive ... (Jullien, 2004: 91).
\end{abstract}

I. The website of the There Forever ephemeral public art project, designed and constructed by Teri Hoskin, is at http://www. ensemble.va.com.au/thereforever

\section{Introduction}

This essay draws upon a project we were both closely involved with - as curator and project manager - titled There Forever. ${ }^{1}$ It was an ephemeral public art project, commissioned for a local community festival, namely the inaugural Port Adelaide Festival in April 2007. The project, made possible by a grant from Arts SA (the South Australian government's arts funding body) involved the curating of eight artists from the city of Adelaide, several of whom knew the local situation in Port Adelaide from living there, but all of whom were aware of the significant and enigmatic suburban history of the port within the context of the city.

Writing a paper by drawing upon a project, in this case an ephemeral art project, raises critical issues of 'use', and, for us, this idea of 'use' carries with it a feeling best described as 'reticence'. This reticence is about writing itself: what it is, what it does, how it can be 'voiced'; and how it is productive of a politics between what can be sensed and how that appears as work. In this essay, two different voices literally come together (there was no pretence at conventional composition), to operate together: left aligned, Linda Marie Walker, right aligned, Stephen Loo.

\section{A question of use}

The Project was, and is, at the mercy of what 'use' is: what 'use' is 'impermanence' (what 'use' is death); what 'use' is investment - money, time, space, thought - in the fleeting, the temporary, the virtual (in other words, life). And integral to The Project was: how to 'use' the given conditions; to think with continually, and to make a set of independent ephemeral artworks, with limited means, limited space, and limited days, so as to form an event without resolution; or, in other words, to form a substance, an awkward or elegant shape, a community of voices, or/and a gathering of moods. Last night Teri Hoskin, an artist in The Project, read from her writing-work for The Project. The piece she read came from the evening of Day 8: 
Waterways around the world are changing - artists and academics sink their teeth into these rich sites of transformation, often funded by developers, local government and councils - cynically one could say we are moved in to make smooth the transformation - yet something else happens which will take a little longer than this time to unfold. The story goes something like this: as sites of transformation post-industrial areas present a rich ground of competing forces of global capitalism, urban renewal, changing work/leisure practices, the impact of new technologies, memory, memorial, etcetera (all those labels that roll so easily off an academic tongue). ${ }^{2}$

The Project's institutional raison d'être is overtly political: to find other ways to commission public art than memorializing (literally) through monuments in space; to tap into the affectual register and thus reify the singularity of the architectural remains of an historic port, as justification for the conservation of place; to engage with a community (and they are not one) whose identity is inscribed in 'historic Port Adelaide' as a name, and so forth. If one has to write The Project as an historical event, how can this writing remain within Jacques Rancière's notion of politics as a process of democratic emancipation from the structures of policy (laws, codes, governance) that deny equality, when writing itself cannot escape from appearing as the material effectuation of/as policy?

More importantly, how can I, as project manager - one already charged with the task of mobilizing policies belonging to sanctioned codes of practice, which in turn relate to 'proper' activities by stakeholders (the governmental art body who funded the project, or the State road and transport authority whose mandate is to police the 'correct' use of public infrastructure) - write The Project as political? The political force of the project is not an identifiable community (The Project does not 'represent', as such, those who have been dispossessed or forced to relocate by rampant urban rejuvenation of the Port), but rather it is the population that has been variously named, and therefore has the possibility of being misnamed (the generic other that each time falls outside a particular distribution of the sensible, whose identity is being invented, or is not yet invented). These are highly specific categories of the public which, paradoxically, exist because of a certain partitioning in the way things can be seen and spoken, internal to institutionalization or governmentality; a public, who by being named, is continuously negotiating its equal status within a given space of community. It is through the subjectivization of the variously and continuously changing public, as a never ending site of verification of equality, that the political emerges (Rancière, 2004b:93).
2. The writing goes on to say: "The question is: how do these sites become choral? Chora - the filter - is an unnameable, unfigurable device (a metaphorical concept invented by Plato and developed by Derrida and after him [Gregory] Ulmer ... through which questions can be framed in such a way that the questions themselves activate thinking action around problems specific to a place and a time." Teri Hoskin's daily venue for her writing was two-fold; first it was the site she chose at Port Adelaide and visited twice a day (dawn/ dusk) and recorded as digital images; twice a day she published a set of images and the writing produced by the commitment to the 'work' of visiting (travelling from her home in the city to the site of The Project, the port) on a web-site (B Part Renaissance: http://ensemble.va.co.m.at/9days/ about.html).

\section{To remain so-touched}

Listening - as the almost-accidental curator of The There Forever Project reminded me of the duty (the love for what is created) one has toward something as delicate and tenuous (and tenacious) as this project was - and still is. Overall, The Project, as a work-of-art named 'ephemeral', had a permanency similar to, but at odds with, the named 'permanent' art-work (it is 'there', permanent, and then vanishes). The ephemeral work offers its absence, its afterwards, as 'real': it appeared; it disappeared. One could fight for its sites 
3. James Geurts' work titled Bridge Drawing Water went through several iterations due to weather; the work eventually became an almost-imagined work; a public bridge was opened by negotiation, a number of ordinary events occurred as a consequence, a very small 'sound-situation' on the water passed beneath the open-bridge, and then the bridge closed (just as it has been doing for decades).

4. Here Rancière is outlining the contradictions inherent in Deleuze's poetics: on one hand Deleuze hopes for an "innocent" multiplicity in texts, on the other he installs the figure of the eccentric as the hero of this multiplicity. For Rancière, the political stake in literature is in the multiplicity in writing's incarnation that arrives from the non-preferential but haecceitic movement of the text in the specific (named) public and text. so-touched to remain so-touched (a lighthouse, a bridge, a building, a wharf, a basement, an archive): they would be 'afterwards' works. (They do remain, in some shape or other, although vaguely 'touched' forever). A site is imagined (the rowboat did not have to be seen; it became sound); ${ }^{3}$ the touched-site is elemental, it continues to be 'the work'. The ephemeral art-work's passing does not make it any less visible (or desirable); its variable duration is not unlike 'an exhibition' in a gallery - it's scheduled, and then it's gone - a minute, twenty five years, or forever (it passes).

Perhaps it is only through a Rancièrean disagreement that I can arrive at the political in writing about the politics of The Project: that is, to enact an interruption to the distribution of the sensible. We do not set out a disagreement of known political positions, nor are we enacting an oppositional practice, but rather a 'dissensus' over the givens of a particular situation made visible by a particular distribution of the sensible. Touching lightly, the writing(s) enact disjunctions and conjunctions between what is meant to speak and to understand, between the visible and the invisible, the audible and the inaudible.

Writing about The Project affords an encounter which causes the objects and utterances to be deterritorialized from their original contextual space of

discourse and temporal designations, so that thinking, as reterritorialization, can begin (again). Thinking is always a rethinking (Rancière, 2000: 120).

\section{Fading}

It was critical that The Project did not cohere into a single state or objective: its times of 'openings' and performances varied; its physical locations were multiple; information was delivered by invitation, website and word-of-mouth. These were not deliberate complications; complexity emerged as forces of containment faded (immediate structure, overarching mood, clear meaning).

In such rethinking is the question of relations and their implicit repetitions and tensions, as manifest in the following conditions: firstly, the elusive material presence of The Project (there were many who claimed that they were unsure if they had missed it altogether); secondly, its presencing as writing, whether representational or otherwise (Rancière would say that writing is always on the way to an incarnation that lies ahead of both writer and reader: "the population of the novel [writing] is also the promise of a people to come" (Rancière, 2004a: 157)4);

and thirdly, the present, the here and now, given by this essay as an evental site.

To unravel The Project would make of it what it did not have the propensity to be; it would impose upon it an 'atmosphere' ruled from elsewhere: the world of art; the world of local-interest; the world of politics (re-development, tourism, business, for instance).

Isabelle Stengers, writing about the "passing fright that scares self-assurance", says that even though fright makes "an interstice in the soil of good reasons" it does not mean "fright is sufficient" to know how to proceed in order to provoke thought and slow down (so as to become aware of "the problems and situations mobilizing us"). Because, "[i]nterstices close rapidly" (Stengers, 2005: 994-996). 


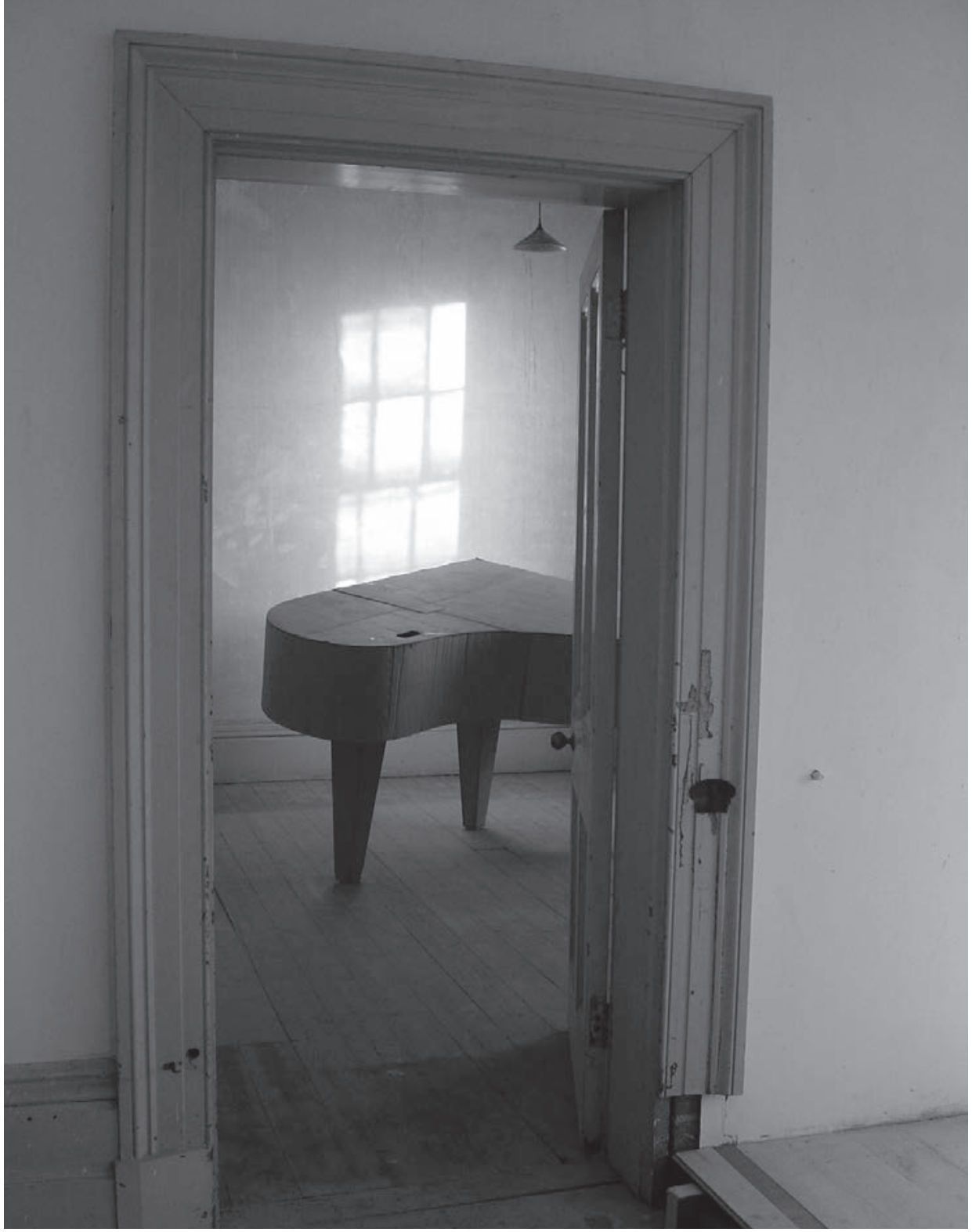

Johnnie Dady, The Cardboard Piano Shop.

The Project kept its diffuse beginning, but with exuberance: talk, disquiet, meetings, excursions, eating, etc. It gathered over time to see what could appear, and to see how not to, if possible, exhaust oneself, and in so doing exhaust the project, the place, the subject; although exhaustion did occur, as did inexhaustiveness - to see what else could be done, with what was understood and by making, performing, and exhibiting the works.

The category of art, as work, whose visibility is primarily given by the image of material instantiation - there-being (of) something on the ground - is frequently appropriated to uncover, represent, enunciate, the politics of public space. A corollary question is whether a work of art can inherently be political?

It seems the question of the aesthetics of a work of art can be found to hover

between the enactment of the politics, and being political in its enactment, resulting in a certain irresolvable undecidability in the politics of aesthetics. It is this metapolitics which Rancière says gives art work its possibilities (2006: 45).

\section{The dream to remain}

That is, 'the work' did not complete itself; it just came to a specified date, a pre-set hour. The permanence of the ephemeral is 'contained', in this instance, in its slowness to sustain a continuation (of making), and to fade from the 'governance of art to manifest non-process, non-transitoriness. The dream to remain, to stay (alive), is not an avoidance of product or market, but is an 


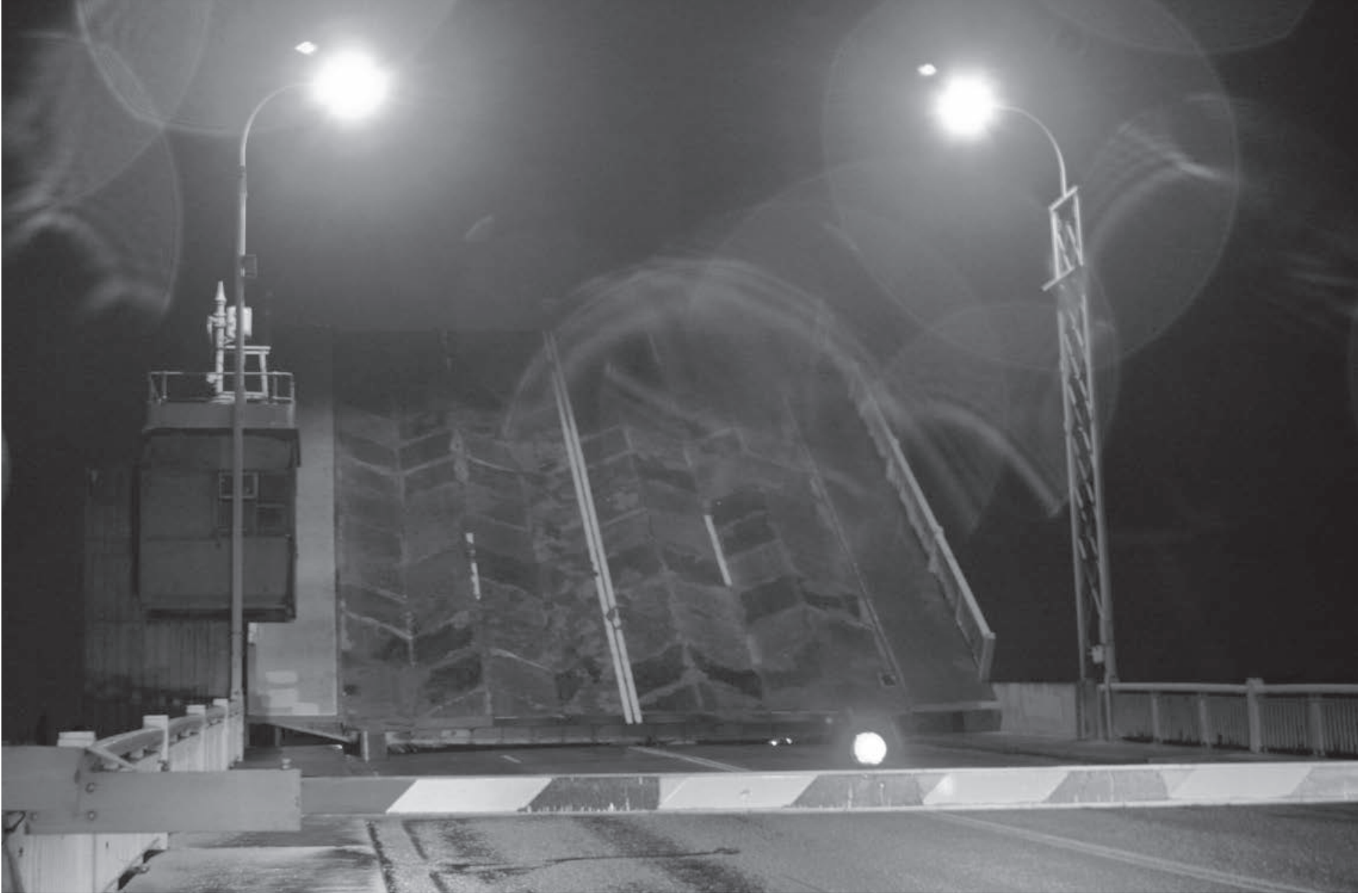

James Geurts, Bridge Drawing Water.

5. "A dissensus is not a quarrel over personal interests or opinions. It is a political process that resists juridical litigation and creates a fissure in the sensible order by confronting the established framework of perception, thought, and action with the 'inadmissible', i.e. a political subject" (Rancière, 2006: 85).

6. The artists: Johnnie Dady, Julie Henderson, Yhonnie Scarce, Angela Valamanesh, Michael Yuen, James Geurts, Teri Hoskin, Jessica Wallace; with Bridget Currie as Research Assistant.

7. They are also not artists who meet the "... market's need for 'spectacle”" (Rancière, 2007: 262). acknowledgment that what arrives at the set-hour is, wonderingly, on 'the way' to something/where else. Therefore, it is implicit to honour what appears by giving it as good a chance as possible to stay-alive (venue, empathy, curiosity, context). For the artist who has taken to heart, or is in the midst of, issues of community, conflict, sadness, anger, loss, and their political effects, determinations, and arguments, 'dissensus' rather than resistance (as a stance, or reaction, in the form of an artefact) is a possible mode of thinking:

... a way of reconstructing the relationship between places and identities, spectacles and gazes, proximities and distances.... The problem, first of all, is to create some breathing room, to loosen the bonds that enclose spectacles within a form of visibility, bodies within an estimation of their capacity, and possibility within the machine that makes the 'state of things' seem evident, unquestionable (Rancière, 2007: 261). ${ }^{5}$

Within the modernist paradigm of public space, the politics of art work is collapsed into the 'public' as an inherently political category: public art effectuates the public politics. Under this regime of effectuation, the concepts of 'public' and 'politics' per se remain coherent, their integrity unquestioned, and they are, in this way, able to afford aesthetics a visibility, as they make available the ground for structuration (for speaking, showing, writing, and making - of essays, research, sculpture, design and architecture, etc.). However, the ground as a place for (other) types of structures, or movements of labour, is never felt or experienced.

\section{Degrees of freedom}

The artists ${ }^{6}$ in The There Forever Project combine mediums - sound, text, drawing, video, objects, light, painting, weaving, photographs, performances. They are not 'multi-media' artists, nor are they artists who primarily work as 'public' artists.' 


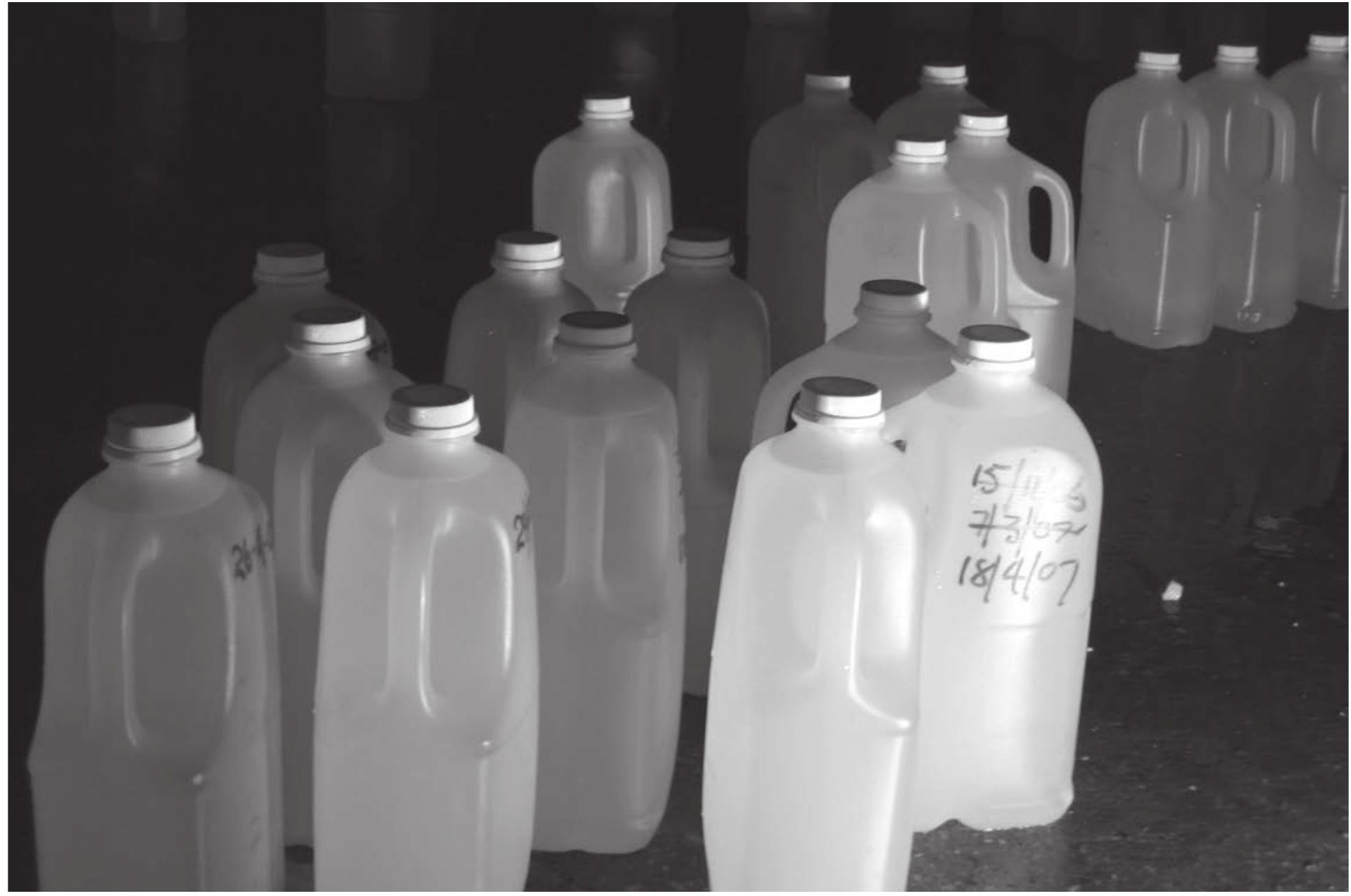

The world has laws of circulation, and degrees of freedom, ${ }^{8}$ and it appreciates the placement of one's feet on the ground: "... of knowing what one is doing in a particular place, in a particular system of exchange. One must find ways to create other places, or other uses for places" (Rancière, 2007: 263). ${ }^{9}$ The rest of my writing for this essay consists of eight fragments written during the making of The Project, to help 'feel' my feet on the ground.

\section{(I) The Labour Of Others}

An expanding practice, where one thing leads to another - a proliferating practice that affects the relationship between things - everything for/to itself, gaps and separations, exact places for thought ... looping to the outside world, the way the body does (connecting to the air); the performance done ...

Perhaps the question becomes: how can we make the ground, as the movement (literally, as kinesis) of labour, political? Or, how do we work with accepted structures and institutions to create new movement structures, ones which are of non-representative politics? ${ }^{10}$ What The Project is (in search of), is a politics of movement not already inscribed with a partisanship, or militancy, or citizenship, but one without a recognized political subjectivity. In The Project, the politico-aesthetics of movement arrives not from planned demonstrations and orchestrated performances, but from the general capabilities of the human

being (for example, the ability to communicate, improvise, hold dissonant beliefs, etc.), as it labours in moving from one definition or name, given in governmentality, to another.
Julie Henderson, Continuous Wave, Forms of a Dialogue.

8. "Freedom is not about breaking or escaping constraints. It's about flipping them over into degrees of freedom. You can't really escape the constraints" (Zournazi, 2002: 222).

9. "The idea of emancipation implies that there are never places that impose their law, that there are always several spaces in a space, several ways of occupying it, and each time the trick is knowing what sort of capacities one is setting in motion, what sort of world one is constructing" (Rancière, 2007: 262).

10. As Deleuze says of intellectual work relating to institutions (he was talking about mental asylums to Foucault), "representation no longer exists, there is only actions - theoretical and practical actions which serve as relays and form networks" (1977: 206-207).
... or not done, the risk is elsewhere, in how we dress, labour, the appearance of labour as art, as the past before us, that things are not over, ever, the making of arrangements, the stories we tell each other, are artefacts, there is no secret, 


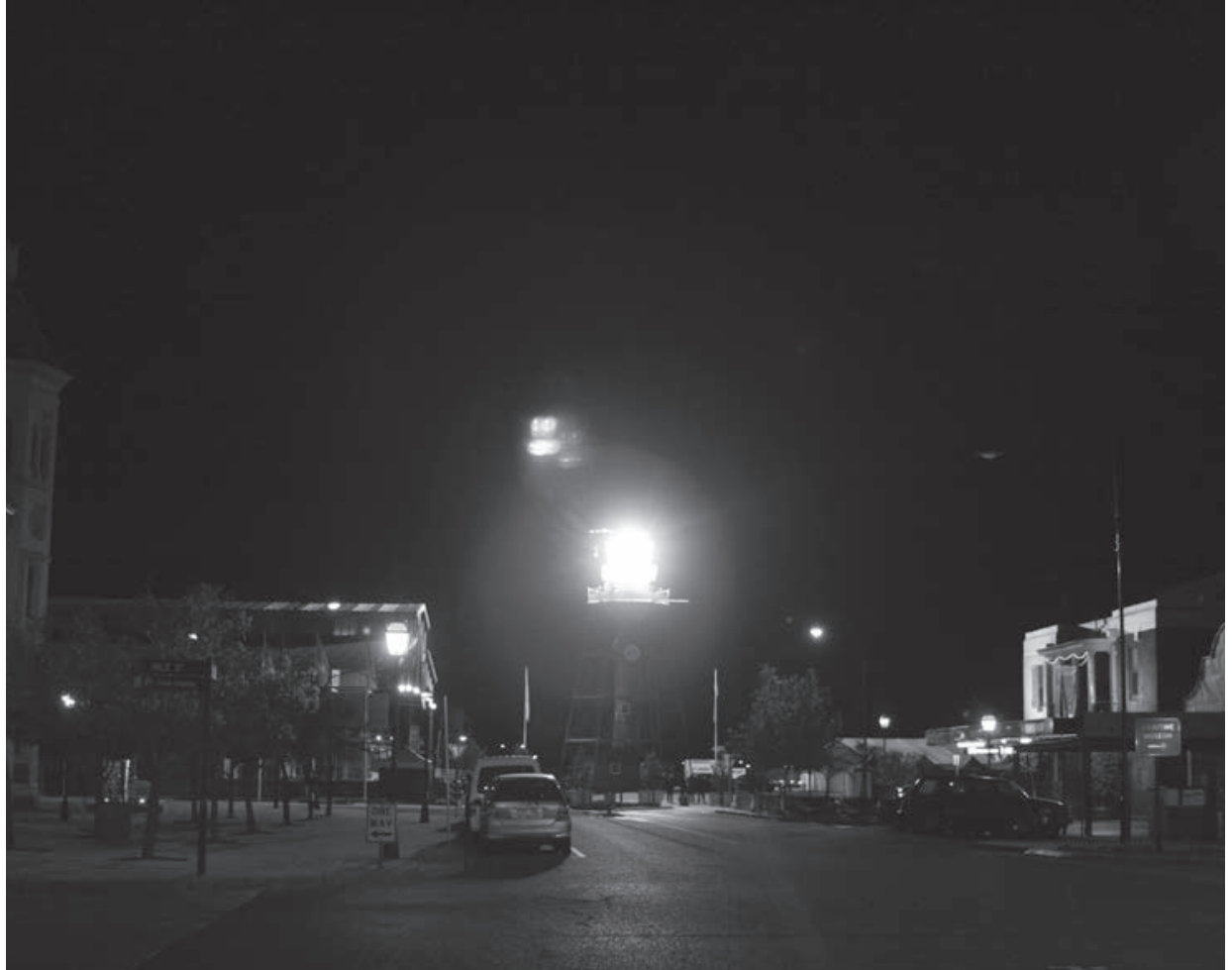

movement is work that needs to be done - an obligation imposed by the metastable system of individuation (Simondon, 1992) as we negotiate belonging to a space. Our citizenship of public space is reliant upon the contingent experience of kinesis (from work associated with drifting migration and emigration, to experiencing artwork, to the use of certain infrastructures and not others, etc.).
Michael Yuen, Flash, Port Adelaide, Australia, 22 April 2007, 8:02pm.

II. "Flash ... is a new ephemeral public work by Michael Yuen. At this place and time: a large flash of light and burst of sound." Michael Yuen, Artist's description, Flash. Port Adelaide, Australia, 22 April 2007, 8:02 pm. at http://ensemble. va.com.au/thereforever

\section{(2) The bridge watching us}

The world comes into view; the things of the world come into view to be acted and touched upon, to be worked 'with', in concert, so as to bring about through constellation, conjunction, intersection, something else again, slight, to the side, upward, or more centred, an image, a slowing of time, a bringing of silence, to listen, to make-out a figure, a boat, who/what that might or might not be, to feel it as oneself, as the self that brought that to its moment, movingly, the aspects, the stopping, the pausing, the resuming, our breath, our willingness, our sadness, our aloneness, and the extreme force of each aspect (a flash, like lightning) - the weight and mechanism of the opening bridge, the pleasure of the bridge-controller, the lights lining the bridge, the sirens and bells, the cars waiting, the rain, the deep currents, the lighthouse weirdly behind us, and the sound of the rower in the boat, passing, and (perhaps) seeing the tiny star-flash of the man on the bridge watching us watching.

\section{(3) Without brief(s)}

There was no brief, no document intended to guide the artists in the project. There were already many shaping conditions though: location, time, festival, money, mediums. And the job was to bring work into existence, from the location itself, work that arose in response to the environment of The Port.

The public gathered in the square, well before time, anticipating a large flash.

After all, this was the name of the work: FLASH. PORT ADELAIDE, AUSTRALIA, 22 APRIL 2007, 8:02 PM. There was going to be light, and sound.11

The space of this almost instantaneous work, and thus the public space in 
12. 'Headquarters' was The Project's main venue, a vacant bank building of architectural significance.
In this way The Project work gives. I am reminded here of Jane Bennett's notion of enchantment: "Enchantment is a feeling of being connected in an affirmative

way to existence; it is to be under the momentary impression that the natural and the cultural worlds offer gifts, and in so doing, remind us that it is good to be alive" (Bennett, 2001: 156). Enchantment is valuable for ethical life because it can supplement, though not replace, a code-based approach to ethics, providing it with a motivational basis and a spirit of generosity that moral rules cannot generate on their own.

'Deano' worked closely with Julie, supplying spotlights and a generator for her performance on the wharf, and then he spontaneously joined in her performance on the night so as to 'help' her cart the water bottles from the shack to the wharf. Rick built Julie a frame for the door to his shed so she could install a tv and video-player to show her film of him talking about his work and the development of The Port. Julie placed an advertisement in the local newspaper calling for old tvs. She received an Aster Plymouth and two lamps, one a small desk lamp. The Astor and the desk lamp became key components of her installation at Headquarters (HQ). ${ }^{12}$

Johnnie Dady's cardboard pianos gently protested against (the) tension that exists between The Old Port and The New Port: aspirations, renaissance, new-life coming from an old-life. You will need a baby grand, surely. And if you're poor, a cardboard one will 'do'. The seven pianos became a community, and they were silent. What does a community have to turn itself into so that you will hear its worth; what does one have to become (beautifully poorly grand) to have a say?

\section{(6) The worry of being worried}

The surface of the space within which this project makes itself and shows itself is not a public or a 'common' space. Unless a specific space is 'designated' a public one 'for art' - agreed upon officially, and then officially offered for the reception of a public work of art that must, to a large extent, meet predetermined interests (monument, commemoration, general good, environmental message) - the surface of the earth, the bits one can find to work with, are subject to highly regulated (impossible) conditions.

What The Project gives are the signs, which give visibility to the sensible, a visibility that is not necessarily there: an image. These signs do not go towards the remembering of historical events. To Jean-Luc Nancy, the image is a re-presentation of the thing to which it owes its ontology, but which competes with the thing in its showing. The image interrupts the self-presencing of the

thing, by bringing the latter to presence; the image is essentially monstrative (Nancy, 2005: 21), a force which deforms the things it shows. An image, in the presentation of itself, forcefully differentiates itself, and the thing it demonstrates, from the chaotic pool of entities or beings.

Everything is, from the outset, approached from the position of 'trouble'. And when one speaks of it, worries what to do, responses are, surprisingly, that this 'trouble' is expected-trouble. The surface, or 'field', upon which one works - to 
produce from and for - appears amidst appearances and is a plane upon planes; it is, actually, dynamic, transitory and replete. The 'public' is a weave of immense complexities: each complexity is an instrument that rules and regulates; each addresses important issues of danger, damage, injury, liability, not issues to ignore, and issues that one must care for; issues for discussion and generosity, not contention and contestation. There is only police/d space.

\section{(7) Trying to speak}

Julie Henderson (and Michael Yuen) spoke to a group of students. Julie talked about the men and women of the radio club (at the Radio Shack), and how her work is slow, and may not have an outcome, even though a performance is advertised for 8pm, 26th April on Fisherman's Wharf. The talk was part of the performance; the artwork is scattered, made of un(in)determinate things and events of different substances that dissolve and spread. Jean Luc-Nancy writes: "Sense is in the exscription of the book, sense is that sense does not stop coming from elsewhere and going elsewhere ..." (1997: 191).

There are many signs given by The Project - images of community, place, history, ecology, architecture, life/lives, death - whose work staves off revelation by signs. These are signs for forgetting, not through emptiness or the void, but by a forestalling of closure that restores the life to remembering.

As Jorge Luis Borges says: in forgetting is the hope that there is nothing to reveal (there are no pre-empted relations), nothing but the revelation that itself does not come about (Nancy, 2005: 26).

The artist labours, is a labourer-artist who can labour differently; the artist can be "... along the surface of this coming of sense. ... praxis is not lacking in him whether as reform or revolt, migration or habitation, pain or joy, invention or routine, or as decision endlessly replayed" (Nancy, 1997: 191). That is, there is 'free' labour, where one is truly (or thereabouts) in the-place or in-servitude (serving place), as one might think one's subject/audience/other is.

But it is not so simple, even though, in all evidence, it is also not the reverse. For the moment, it remains - and it seems to me urgent - to say the following: let us not decipher the world in terms of our philosophical melancholy - no more than in terms of a maniacal optimism that is another form of the same thing. But let us learn to think toward the world (Nancy, 1997: 191).

Here, the relations are imminent, always coming, hovering.

\section{(8) A man on an open bridge}

A man walks halfway across a bridge

From a long way away someone sees a man walk halfway across a bridge

There were biomorphic pinnacles in a dark basement. And two sun deck chairs. 
13. Yhonnie Scarce's two black painted canvasses were slowly stitched with red thread (this thread pushed through the hard material surface, causing the whole hand to feel pain, and to have to find ways to manage this process; the stitches bear the inscriptions of various affectual forces related to the challenges faced by the artist in the duration of the work, including questions concerning the cultural nature of the work, and threats to the artist's personal security), following intuitively an inner 'track', based on her own indigenous family's itinerant story, and working the red lines back and forth; working on the floor in public for hours and days, and having to feel the presence of others attending to her work or ignoring her; and then these pieces being suspended at $\mathrm{HQ}$ on closing night, where they formed an internal shelter of some strange solid kind.
He stops to watch someone a long way away, across the water he thinks someone is watching him there

he thinks they see him

New Metaphors is an interplay between the enchantment by the image which holds apart the actual landscape, and the interconnectedness of art and the ecosystem in a best fit selection. In the first condition, the material appearance of Angela Valamanesh's work may be read, rationally, as symbolic images of an ecosystem.

As a man standing on a bridge he thinks of a boat in the water beneath him

He stops to look across from him, to slow down, to see the other one he thinks he sees

He hears around him what he has never heard before

it sounds like he is what he hears

that this is what he is, inside himself

In the second, the morphological transformations in the art work mirror an ecology of practices involving environmental, social and mental systems, which, owing to the constant presence of ambiguity in reading, create conundrums in attempts at a Platonic theory of beauty associated with truth.

Perhaps it is Yhonnie Scarce, in her Fanny Graham, that demonstrates most clearly the work of art as political, through its transformations between human affectual or biological relations, and non-human materiality, not only in imaginative terms, but also in terms of real relations, as actively constituting the places in which we live.

He hears himself as a man on a bridge

Across the water someone hears what there is to hear that they have never heard before

It is the sound of a man on a bridge

They think of a boat in the water beneath him

The red yarn, worked with, at times, difficult human labour ${ }^{13}$ into a material surface that itself bears the marks of human movement (being trod, danced, tripped on), and the movement of the work itself (it was dragged to various locations, folded and unfolded, hung). As the ground, surface

or terrain for movement that is the confrontation between what can be sensed (by way of names, institutions, culture, habits) and the attempts by the public to verify their worth, 'use', and, therefore, equality in such partitionings of the sensible, the work of art emerges as a political agent with which we, as the named public, are entwined, and it is complicit in the emergence of our public places (its aesthetics is immanent to 'being-there'), and the ways we comport to these places. 
It sounds to them like something they've heard before too, somewhere else They take a photograph of him, they take a photograph of the sound of a man on a bridge, a man they think they see on a bridge

He takes a photograph of someone he thinks he sees a long way away, inside the sound of himself, then he walks back across the bridge

(Everything else happens in the world $)^{14}$

\section{References}

Bennett, J. (2001). The Enchantment of Modern Life: Attachments, Crossings, and Ethics. Princeton: Princeton University Press.

Deleuze, G. (1977). Intellectuals and Power. In Foucault, M. Language, Counter-Memory, Practice: Selected Essays and Interviews by Michel Foucault, D. F. Bouchard (Ed.). Ithaca: Cornell University Press.

Jullien, F. (2004). In Praise of Blandness: Proceeding from Chinese Thought and Aesthetics (P. M. Varsano, Trans.). New York: Zone Books.

Nancy, J. L. (1997). The Sense of the World (J. S. Librett, Trans.). Minneapolis \& London: University of Minnesota Press.

Nancy, J. L. (2005). The Ground of the Image (J. Fort, Trans.). New York: Fordham University Press.

Rancière, J. (1999). Disagreement: Politics and Philosophy. Minneapolis: University of Minnesota Press.

Rancière, J. and Panagia, D. (2000). Dissenting Words: A Conversation with Jacques Rancière. Diacritics 30 (2, Summer), 113-126.

Rancière, J. (2004a). The Flesh of Words: The Politics of Writing (C. Mandell, Trans.). Stanford: Stanford University Press.

Rancière, J. (2004b). The Politics of Aesthetics: The Distribution of the Sensible (G. Rockhill, Trans.). London and New York: Continuum.

Rancière, J. (2006). The Aesthetic Revolution and its Outcomes. In Heart of Darkness: Kai Althoff, Ellen Gallagher and Edgar Cleijne, and Thomas Hirschhorn. Minneapolis: Walker Art Centre.

Rancière, J. (2007). Art of the Possible: In Conversation with Jacques Rancière. Art Forum (March), 261.

Simondon, G. (1992). The Genesis of the Individual. In J. Crary and S. Kwinter (Eds.). Incorporations, Zone 6. New York: Zone Books.

Stengers, I. (2005). The Cosmopolitical Proposal. In B. Latour and P. Weibel (Eds.). Making Things Public: Atmospheres of Democracy. Cambridge: The MIT Press.

Zournazi, M. (2002). Hope, New Philosophies for Change. Annandale: Pluto Press Australia, Annandale.
14. This last fragment was written in response to the performance work Bridge Drawing Water by James Geurts on 29 ${ }^{\text {th }}$ April 2007. 